\title{
The Problems Associated with Enzyme Purification
}

\author{
Etienne Dako ${ }^{1}$, Anne-Marie Bernier2, \\ Adjéhi Thomas Dadie ${ }^{3}$ and Christopher K. Jankowski ${ }^{1}$ \\ ${ }^{1}$ University of Moncton, Moncton, NB \\ ${ }^{2}$ University of Saint-Boniface, Winnipeg, $M B$ \\ 'University of Abobo-Adjamé, Abidjan \\ 1,2Canada \\ ${ }^{3}$ Côte d'Ivoire
}

\section{Introduction}

This chapter aims to highlight the difficulties encountered during the purification of native cellular and membrane-bound enzymes from whole cell extracts. There are many reasons for wanting to purify enzymes, such as to fully characterize them or to mass produce them for commercial purposes. Regardless of the reason for wanting to purify an enzyme, the general extraction and purification procedures are essentially the same. However, depending on the properties of the enzyme, certain modifications of the methods must be considered regarding specific problems that can be encountered throughout the process, such as enzyme insolubility and loss of enzyme activity. Although several classic and more modern methods are available to solve these kinds of challenges, the enzyme purification step remains a major challenge for any method of extraction used.

We will present the general aspects of enzyme purification, followed by a specific example of the problems we encountered and attempted to resolve in the purification of the autolysin PA49.5 from Lactococcus lactis subsp. cremoris. Autolysins are bacteriolytic enzymes that digest the peptidoglycans of bacterial cell walls (Dako et al, 2008). In several studies it was found that autolysins are linked to lipids or other membranous components during the extraction process and especially during the purification. Since they are very closely linked to the cell walls, their purification presents major challenges associated with their low concentration, their insolubility and the retention of their biological activity (Marshak et al., 1996; Brown et al., 1970). Among these difficulties, their insolubility during purification remains by far the most serious and examples of how we tried to resolve this problem will be presented.

We can look at the process of enzyme purification as a series of steps, each one sequentially enhancing the level of purification from a crude extract. It is essential to minimize protein losses throughout the process; therefore the use of fewer steps during the purification is important since losses can occur in every step due, for example, to linking to separation matrices, insolubilities, or losses into the fringe fractions during separation procedures. We will look at the general steps in the extraction of proteins from the cells, the clarification of the homogenate, the concentration or enrichment of the extract, and finally various steps in 
the final purification of the enzyme. A purification strategy can be made more efficient if certain physical or chemical properties such as molecular weight, optimal $\mathrm{pH}$, isoelectric point, of the enzyme are known.

To follow the efficacy of the purification of the target enzyme from a whole cell extract there must be a method of measuring its presence throughout the process to ensure the maximum yield. These assays can be an assessment of biological activity or assays based on reactions with antibodies. The antibody assays however do not necessarily indicate if the enzyme is in an active conformation. The assays based on catalytic activity do however require that the enzyme retain its active conformation, which can be problematic since many components of the extractions buffers contain compounds such as detergents that denature the tridimensional structure of the enzyme. Compounds compatible with enzyme assays must therefore be used to minimize losses of activity. The isolation of certain types of enzymes may present problems specific to those enzymes. For example, some problems most often associated with the purification of membrane proteins are that they require organic solvents or detergents for their solubilization. Also, insoluble enzymes may require the use of stronger chaotropic compounds such as lithium chloride or guanidine HCL that can in turn inactivate the enzyme. In order to be able to fully characterize the biochemical properties of a purified enzyme, it must be completely free of contaminants such as cell wall or cell membrane components, nucleic acids or other proteins. The complete removal of contaminants is, therefore, the primary objective of the purification. These contaminants can interfere with subsequent purification steps or with enzyme activity assays. The purity of an enzyme extraction can be confirmed, for example, by the presence of a single band on an electrophoretic gel (SDS-PAGE or isoelectric focusing), a single peak in an HPLC analysis or by $\mathrm{N}$-terminal amino acid sequencing.

The initial step in all protein purification protocols is the release of the enzyme from the cell or tissue material, or cell extract preparation. This is a critical step in the process as it affects protein yield and biological activity of the target enzyme. This naturally requires either a mechanical or chemical lysis of the cells. Methods for homogenizing cells or tissues vary from gentle methods such as osmotic shock, detergent lysis or enzymatic digestion to more vigorous methods such as homogenization in a blender, grinding with an abrasive substance or ultrasonication. The lysis procedure selected must not damage the target enzyme and therefore the conditions must be optimized for each cell type and target enzyme in terms of the $\mathrm{pH}$ of the extraction buffer, the temperature and the concentration of certain components of the buffer such as detergents, salts or reducing agents for example. Reducing agents such a dithiothreitol or 2-mercaptoethanol can be used to prevent the oxidation of sulfhydryl groups that could damage the active conformation of the enzyme resulting in a loss of activity (Ward \& Swiatek, 2009; Chen et al., 2010). Detergents or organic solvents, generally used to isolate hydrophobic or membrane bound enzymes, can be problematic in subsequent purification steps as well as interfere with the native conformation of the enzyme. It is essential also to consider subsequent purification steps when choosing a detergent. Certain downstream applications such as optical spectroscopy, mass spectrometry and crystallization, can be negatively affected by the presence of some detergents (Linke, 2009). There are various detergents available and these will be discussed further in the section of enzyme purification. The most important criteria for the selection of a detergent for the 
solubilization of a protein is its ability to not only solubilize but to maintain biological activity. In general, the detergents with higher critical micelle concentrations (CMC) can more easily denature proteins than those with lower CMC (Linke, 2009; Lever et al. 1994; Garavito, 1991; Hjelmeland \& Chrambach, 1984), and it must be used at concentrations above its CMC in order to effectively solubilize the proteins (Privé, 2007).

Once the cell or tissue homogenate is produced, the cell debris and other insoluble compounds must be removed by centrifugation. The optimal situation is that following a high speed centrifugation, the solubilized proteins will be in the supernatant along with other soluble compounds, and that all insoluble material will be in precipitate. Sequential or differential precipitations can be performed to progressively remove cell debris in order to rehomogenize it to enhance protein yield or to isolate specific cell organelles if the starting material is eukaryotic. Following this clarification, the cell extract is then ready to be purified in an enrichment or concentration procedure.

A process that can be considered after the clarification is the concentration of the enzyme preparation. Dialysis can be performed prior to the concentration procedure in order to remove salts from the cell extract. The clarified cell extract can therefore be dialyzed against a large volume of buffer to remove salts and the dialysate can then be lyophilized to concentrate the extract. Lyophilisation, or freeze-drying, has the advantage of protecting the protein from the chemical reactions that can damage the proteins in an aqueous solution, such as aggregation, precipitation and protease degradation ( $\mathrm{O}^{\prime}$ Fagain 2004). The protein extract can then be stored in the lyophilized state and aliquots resuspended as needed.

The most common concentration procedures are ammonium sulfate precipitation, ultrafiltration and ion exchange chromatography (Ward \& Swiatek, 2009).

There are two applications of ammonium sulfate precipitation. The first one is a complete precipitation in which all proteins are precipitated by the addition of the salt. The proteins are recovered by centrifugation and resuspended in a minimal volume of water and are therefore concentrated. The residual salt must be removed by dialysis as it can interfere with protein activity or subsequent purification steps. One of the problems encountered with the dialysis of a protein extract is that the protein can precipitate onto the walls of the dialysis tubing thereby impairing the passage of particles across the membrane. This would be particularly problematic in the dialysis of a crude cell extract (Doonan, 2004a). The salts cause the precipitation of proteins by removing water from the hydrophobic patches on the protein's surface, thus rendering them insoluble (Doonan, 2004b). Another approach to the concentration of a cell extract is a fractional precipitation using a salt. Again ammonium sulfate is the most frequently used salt, because of its high solubility and the fact that the density of saturated solutions is less that of the protein. This allows the collection of proteins by centrifugation (Doonan, 2004b). The fractional precipitation is done by incrementally adding amounts of ammonium sulfate and collecting the fractions precipitated by various salt concentrations by centrifugation. Fractions can, for example, be collected at each increment of $20 \%$ concentration of salt. Each fraction can be analyzed for the enzyme in question. This will therefore concentrate the cell extract and also begin the process of purification. Depending on the solubility of the protein it may however be found in more than one fraction. The combination of these fractions will increase the yield of the enzyme however this will also reduce the level of purification. 
Ultrafiltration is based on the principal of separation through a semi permeable membrane filter. Many filter type units are available commercially, either applying a centrifugal or stirred cell type of separation (Bonner, 2007). The principal for all ultra centrifugal methods is the filtration through a membrane that has a selective molecular weight cut off point, therefore it will separate the extract based on the size of particles, not the charge.

Ion exchange chromatography is a non affinity absorption method that purifies proteins on the function of molecular charge, not the molecular weight. The resin in the chromatography column is either negatively or positively charged. Proteins also have a charge that will be dependent on the $\mathrm{pH}$ of the extract or solution. The principal of ion exchange chromatography is to pass the protein extract through the column at a $\mathrm{pH}$ where the protein will adhere to the oppositely charged matrix. The $\mathrm{pH}$ is then gradually changed during the chromatography and the proteins will be eluted when their charge is neutralized by the $\mathrm{pH}$ of the elution buffer. Fractions are collected from the column and analyzed for enzyme activity to identify the fraction containing the enzyme in question (Bonner, 2007).

There are no set protocols or sequences of procedures that will ensure the purification of an enzyme from a cell extract. These will vary according to the source of the enzyme and the specific properties of the enzyme.

To better understand the difficulties and techniques of extraction and purification, we decided to present a specific example, that of the lytic membrane enzyme PA49.5 so named for its molecular mass of $49.5 \mathrm{kDa}$. This enzyme was isolated from Lactococcus lactis subsp. cremoris ATCC 9596 denoted MC5. The objective of our study was to find a non-denaturing method to solubilize the autolysin in order to ensure its purification to a point that would allow its biochemical characterization. The extraction of PA49.5 from a crude cell extract supernatant, from cell wall debris and whole cells was attempted using different approaches in order to attempt to maximize solubilization of the enzyme. Extracts were further solubilized in various detergents and organic compounds and subsequently further purified by HPLC, ion exchange chromatography or ammonium sulfate precipitation.

In view of their richness in ripening enzymes (Dako et al. 2008; Dako et al. 1995), lactococci play an essential role in the production of cheese. These microorganisms also contain lytic enzymes known as autolysins because of their capacity to degrade the membranes of the bacteria that produce them. A few examples of the autolysins are: $\mathrm{N}$-acetylmuramidases, $\mathrm{N}$ acetylglucosaminidases, N-acetylmuramyl-L-alanine amidase and peptidases (Dako et al., 2003; Valence et Lortal., 1995; Shockman et Höltje, 1994; Kawagishi et al., 1980). These autolysins have an effect on specific areas in the $B-1,4$ bonds between the $\mathrm{N}$ acetylglucosamine and the N-acetylmuramic acid (N-acetylglucosaminidases, Nacetylmuramyl-L-alanine amidases) or between $\mathrm{N}$-acetylmuramic and $\mathrm{N}$-acetylglucosamine (N-acetylmuramidases). Since they are very closely linked to the cell walls of these bacteria, the isolation of autolysins presents major difficulties associated with their low concentration, their insolubility and the retention of their activity (Marshak et al., 1996; Brown et al., 1970). Among these difficulties, the insolubility of autolysins during purification remains by far the most serious problem. This is due to the presence of teichoic (Lortal et al., 1997) and lipoteichoic (Fisher et al., 1980; Höltje \& Tomasz, 1975) acids. 
According to Brown (1972), the problem of the solubility of enzymes during purification is linked to the presence of material other than autolysins, which absorb strongly at 260 to $280 \mathrm{~nm}$. According to Shockman et al. (1967), the treatment of the cell wall by sodium dodecyl sulfate (SDS) would resolve the problem of the insolubility of the autolysins of lactic bacteria during purification. SDS is the most widely used detergent to solubilize most otherwise insoluble proteins such as autolysins (Dolinger et al., 1989), its presence may affect the tertiary structure of proteins because it is one of the most strongly denaturing detergents. It is also one of the most difficult to remove with dialysis. The renaturing of SDS extracted proteins after electrophoresis in denaturing conditions does not totally eliminate the SDS, even if it allows the activity of lytic proteins (Lortal et al., 1997) to be measured. Thus, we propose that the use of other non ionic (Triton X-100) or zwitterion (CHAPS) non-denaturing detergents will have the advantage of resolving the problem of the insolubility of autolysins whilst protecting their structure. In general, the detergents such as CHAPS and those that possess a cholanoic group such as cholate all produce very small micelles and have a critical value of micellar concentration (CMC) below $2 \mathrm{mM}$. The CMC is the value above which there is the formation of micelles (Hjelmeland et Chrambach, 1984; Helenius et al., 1979). These detergents can be eliminated by dialysis without affecting the protein activity (Hjelmeland et Chrambach, 1984). The main aim of this study was to find a non-denaturing method to solubilize the main autolysin (PA49.5) of L. lactis subsp. cremoris ATCC 9596 (Mc5) so as to ensure its purification from the supernatant of cellular remnants and whole cells.

In several studies it was found that autolysins are linked to lipids or other membranous components during the extraction process and especially during the purification. They are therefore considered to be hydrophobic enzymes; however, it is often unclear whether or not the enzyme of interest is in fact hydrophobic. Although several classic and more modern methods are available to solve these kinds of challenges, there is still much uncertainty, and further studies are still needed to clearly resolve the purification of cell membrane hydrophobic enzymes.

An important observation, reported by Brown et al (1970), is that autolysins are associated to teichoic acid in the cell wall of Bacillus subtilis. These authors propose that this acid can be eliminated by ethanol precipitation and by gel filtration on an agarose column. Their finding did not confirm this hypothesis, in fact, they found that only $5 \%$ of the techoic acid was eliminated using this method. This acid also persisted after multiple washes with ethanol or ether, and it persisted after separation in a polyacrylamide gradient density gel electrophoresis, ion exchange chromatography and gel filtration using 7M urea.

After many attempts, certain autolysins were purified by electrophoresis using SDS as the detergent ( $\mathrm{N}$-acétylglucosaminidase, ac- $\mathrm{N}$-acetylmuramidase and ac- $\mathrm{N}$-acetylmuramyl-Lalanine amidase) (Motoyuki et al. 1995). Brown (1972) suggests that the purification of autolysines from lactic bacteria is only possible in the presence of SDS. While SDS is an excellent approach to the purification of this type of enzyme, we propose that another method must be found in order to eliminate the compounds that bind to the autolysin thereby rendering it insoluble. CHAPS, a zwiterrionic detergent, used at high temperatures was evaluated as a potentially more efficient detergent in the purification of this enzyme. 
We will present our attempts to purify the enzymes using these various strategies and the problems encountered during certain steps. Some approaches were more problematic that others while some hold more promise in the purification of the enzyme in question.

Before looking at the specific details of how we attempted to purify this autolysin, we will present the assay we used throughout these experiments to verify the presence and purity of our enzyme. For all extractions, a protein profile was examined by SDS-PAGE stained with Coomassie blue. Molecular weight markers were included in all gels. In order to identify autolysins in the preparations, a sample was analyzed by a denaturing SDSPAGE containing intact cell walls from Lactococcus lactis sp cremoris MC5 as the substrate for the autolysin according to the method of Potvin et al. (1988). The gel was renatured in buffer containing Triton X100, and enzyme activity was noted by the presence of a clear zone surrounding the enzyme band after staining with Coomassie blue. Proteins were quantified using the method of Lowry. It is also possible to test for general autolysin activity by agarose gel diffusion in a Petri plate. The gel contains cell wall fragments and the fractions containing the autolysin are introduced into wells perforated into the agarose. The gel is incubated and the presence of autolysins is then observed by the presence of a clear zone surrounding the well.

Three different methods of preparing cell extracts were tried in this work, either using autolysis, cell debris or whole cells. We initially started with a crude cell extract prepared by autolysis and the mechanical breakage of the cell. Washed and precipitated cells were suspended in a citrate lysis buffer containing $2 \% \mathrm{NaCl}(\mathrm{w} / \mathrm{v})$ and $0,3 \mathrm{M} \mathrm{LiCl}$. The cells were incubated at $30^{\circ} \mathrm{C}$ for 48 hours to ensure maximum autolysis. The cell debris precipitated by centrifugation was ground with alumina and the supernatant was combined to the first supernatant. These combined supernatants were dialyzed to eliminate the salts, the dialysate was filter sterilized and lyophilized and the extract was then concentrated 28X. This crude extract (CE) was then separated by preparative HPLC which separates the proteins by molecular weight. High molecular weight proteins are found in the first fractions, in the mobile phase. The fractions collected were dialyzed and lyophilized. Autolytic activity of the HPLC fractions was determined by SDS-PAGE with the cell wall substrate.

Four peaks were observed in the HPLC separation profile, the first and largest peak had a retention time of 6 minutes and contained proteins with molecular weights greater than 30 $\mathrm{kDa}$ and represented $57,45 \%$ of the total estimated area. The autolysin PA49,5 was found in the first fraction as shown in figure 1. C5 represents the results from Lactococcus lactis subsp. cremoris ATCC 9596 denoted MC5. A visible clear zone can be seen surrounding the wells. Figure 2 presents the results of a denaturing polyacrylamide gel containing cell walls as substrate to identify specific autolysins separated by molecular weight during the electrophoretic process. We can see on figure 2 that there is one band of activity for a protein with the molecular weight of 49.5 .

In comparing the protein profile of the crude extract with the proteins in fraction 1, we saw that fraction 1 had approximately $40 \%$ less protein than the crude extract indicating that a certain level of purification had been obtained. While the starting crude extract was concentrated $28 \mathrm{x}$, we required $30 \mu \mathrm{g}$ of fraction 1 proteins to observe autolytic activity. This confirms the limitations of molecular sieving as a method of purifying autolysins. 
The autolysins identified in the peak 1 were evaluated in order to determine whether they are acidic or basic proteins. The Davis gel electrophoresis, which allows the identification of acidic proteins, revealed autolytic activity of a band migrating to molecular weight 49.5. The Reisfeld gel that allows the identification of basic proteins revealed no autolytic activity. We can therefore conclude that autolysin P49.5 is an acidic or neutral protein. Since the protein was in the upper area of the Davis gel it is more probable that the protein tends to be more of a neutral $\mathrm{pH}$.

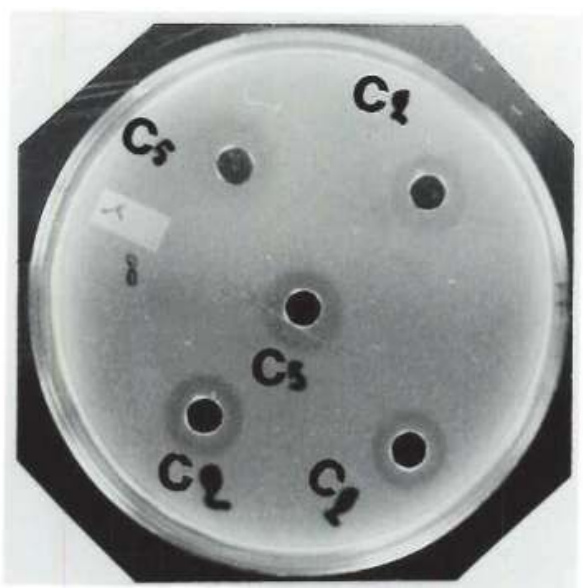

Fig. 1. Gel diffusion assay of HPLC peak 1 on agarose containing cell walls as autolysin substrate.

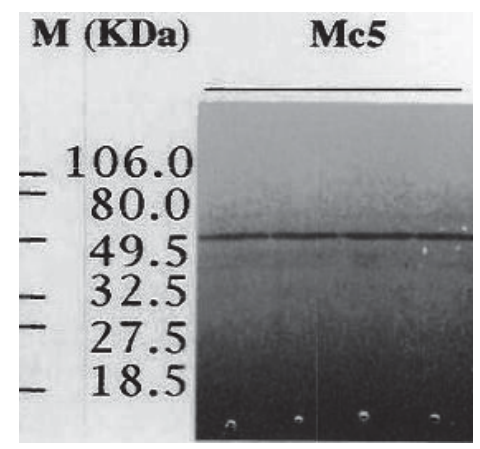

Fig. 2. Autolytic activity of PA49.5 in fraction 1 obtained by HPLC after 48 hours of renaturation.

We determined that the concentration of protein present in $575 \mathrm{mg}$ of fraction 1 extract diluted in $250 \mathrm{ml}$ of buffer was $0.17 \mathrm{mg} / \mathrm{ml}$. Using the following formula, we calculated that proteins constitute only $7.4 \%$ of the fraction 1 extract. This again demonstrates that a better method is required if a large quantity of the enzyme in question is to be purified.

$$
\% \text { Protein }=\frac{[\text { protein concentration } x \text { dilution volume }] \times 100}{\text { Amount of crude extract }(\mathrm{mg})}
$$




$$
\begin{gathered}
\% \text { Protein }=\frac{\left[0.17 \frac{\mathrm{mg}}{\mathrm{ml}} \times 250 \mathrm{ml}\right] \times 100}{575 \mathrm{mg}} \\
\% \text { Protein }=7.4
\end{gathered}
$$

Large concentrations of salts are generally used to precipitate proteins from cell extract. Ammonium sulfate is the salt of choice as it can be used in lower concentration than other salts and it preserves the biological activity of proteins. In a solid state, the salt can be added gradually to a mixture with constant mixing and fractions collected at various levels of saturation. Ammonium sulfate reaches its saturation point at $760 \mathrm{~g} / 1$ at $4^{\circ} \mathrm{C}$.

Peak 1 from the HPLC preparation was lyophilized and then the lyophilisate was resuspended in buffer, centrifuged to remove insoluble material and the supernatant was precipitated using ammonium sulfate. In order to ensure an efficient precipitation, a minimal concentration of $1.0 \mathrm{mg} / \mathrm{ml}$ of protein is required. We therefore measured the protein content of our supernatant or crude extract before proceeding. Four fractions were collected by sequential precipitations $(0-20 \%, 20-40 \%, 40-60 \%, 60-80 \%)$. For example the first precipitation was obtained adding enough ammonium sulfate to obtain $20 \%$ saturation. The mixture was centrifuged, the precipitate was conserved and the supernatant was further precipitated with another addition of ammonium sulfate up to $40 \%$ saturation. This process was repeated with $20 \%$ increments of ammonium sulfate saturations, to $60 \%$ and $80 \%$. The precipitates obtained were dissolved in deionized water, dialyzed and then concentrated by ultrafiltration with a Microcon-10 filtration system. The quantity of protein was measured in all precipitates and supernatants collected.

Our results indicate that we recovered only $26.3 \%$ of the initial protein during the sequential precipitations. One of the important steps following the precipitations is the ultrafiltation using the Microcon-10 whose membrane allows the exclusion of proteins based on molecular weight, or size exclusion. This step could explain the loss of protein during the process. This ultrafiltation does however offer the advantage of rapid salt removal and a rapid concentration of proteins. The membrane used in our experiment removed high molecular weight proteins.

The diffusion autolytic test in an agarose plate containing cell walls as the enzyme substrate indicated that all ammonium sulfate fractions except the $0-20 \%$ fraction had some autolytic activity as indicated by a clear zone surrounding the well. The control, which was the crude non precipitated extract had no autolytic activity, however this is certainly related to the low concentration of autolysins in this extract. The precipitated fractions were then analyzed for specific PA49.5 activity using the gel electrophoresis in denaturing conditions. The results are presented in figure 3 . Lane 1 is the control which was the $0 \%$ ammonium sulfate. Lanes 2 to 5 are the precipitated fractions $(0-20 \%, 20-40 \%, 40-60 \%$ and $60-80 \%)$. We can see that the $40-60 \%$ fraction contained the most autolysin 49.5 .

The complete protein profile of peak 1 as determined by SDS-PAGE is shown in Figure 4 . Lane T5 is the control unprecipitated extract, lanes $1-4$ are $1 \mathrm{mg} / \mathrm{ml}$ of protein, lanes 5 to 8 are $1.5 \mathrm{mg} / \mathrm{ml}$ protein for each of the fractions $0-20 \%, 20-40 \%, 40-60 \%$ and $60-80 \%$. The complete protein profile shows us that there are still many contaminating proteins in our extracts, and that there is little difference in the profile between the different concentrations. The crude extract is quite poor in proteins primarily due to a dilution factor. The protein 
content of fraction $0-20 \%$ is also quite low and the concentration of proteins increases with each fraction collected.

The whole cell extract was also precipitated using ammonium sulfate to compare the autolysin profile with that obtained from the HPLC peak 1 . The results are presented in figure 5 for each of the four collected fractions at two different protein concentrations. Autolysin PA49.5 is the primary autolysin extracted and it is present in all fractions except the $40-60 \%$ fraction (lanes 3 and 7). The intensity of the band in fraction $60-80 \%$ (lanes 4 and 8 ) is approximately half that of the fractions $0-20 \%$ and $20-40 \%$ and $40-60 \%$. Once again the control does not contain the autolysin due to a low concentration of autolysin in the initial extract. This also demonstrates that ammonium sulfate precipitation not only separates the proteins but also concentrates them. The fact that we found the autolysin in many fractions does however indicate the limitation of this method of its purification and the problem encountered by the difficulty in solubilizing this protein. The ideal situation would be to find the autolysin in one fraction only.

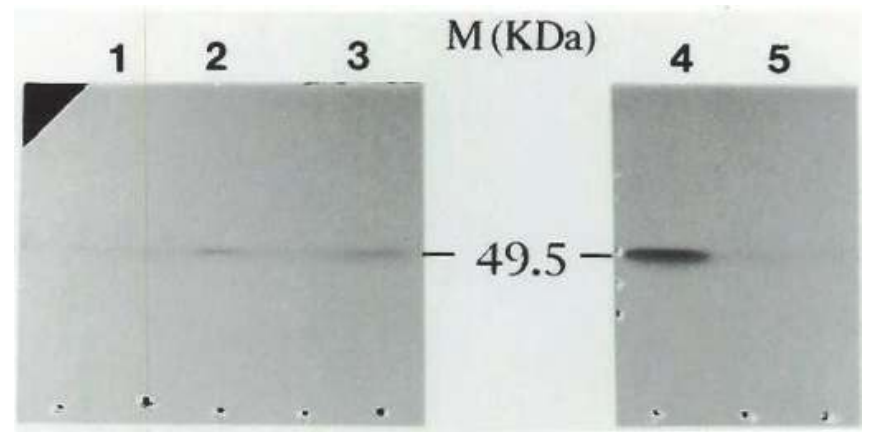

Fig. 3. Autolysin activity of ammonium sulfate precipitated HPLC peak 1.

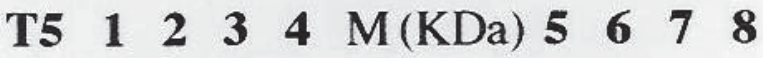

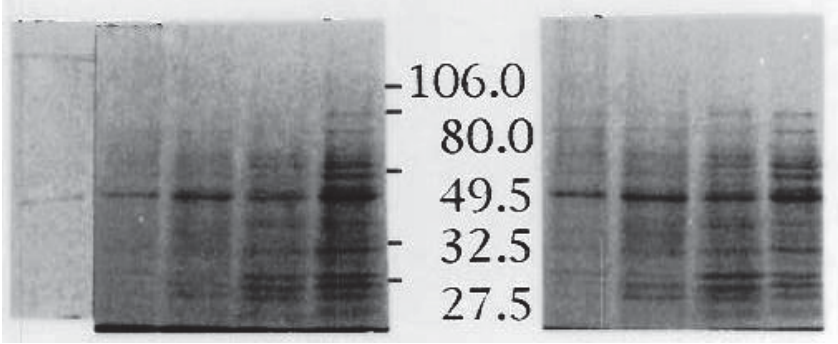

Fig. 4. The complete protein profile of peak 1 of from the HPLC analysis.

Each ammonium sulfate fraction from the peak 1 precipitation was then separated by ion exchange chromatography (DEAE Sephadex A-50). There were important losses of protein content from each fraction after this separation. For example, fraction $20-40 \%$ contained $0.510 \mathrm{mg}$ of protein at the start of the chromatography. When the protein content of all the 
chromatography fractions eluted with $\mathrm{NaCl}$ are combined, we recovered $0.246 \mathrm{mg}$ of protein, or $48.24 \%$. The lowest protein recovery was from fraction $0-20 \%$ with $26.6 \%$ of the protein recovered. When these fractions were assayed for autolysin activity by SDS-PAGE with cell wall incorporated as the substrate, the only fractions that had autolytic activity were from $0.0,0.25$ et $0.5 \mathrm{M} \mathrm{NaCl}$ with the the $0-20 \%$ ammonium sulfate fraction and the $0.25 \mathrm{M} \mathrm{NaCl}$ fraction from the $20-40 \%$ et $40-60 \%$ ammonium sulfate fractions. Once again we see that the autolysin is present in various fractions. This poses a serious problem regarding the insolubility of PA49.5 which limits the use of ammonium sulfate precipitation and ion exchange chromatography in its purification.

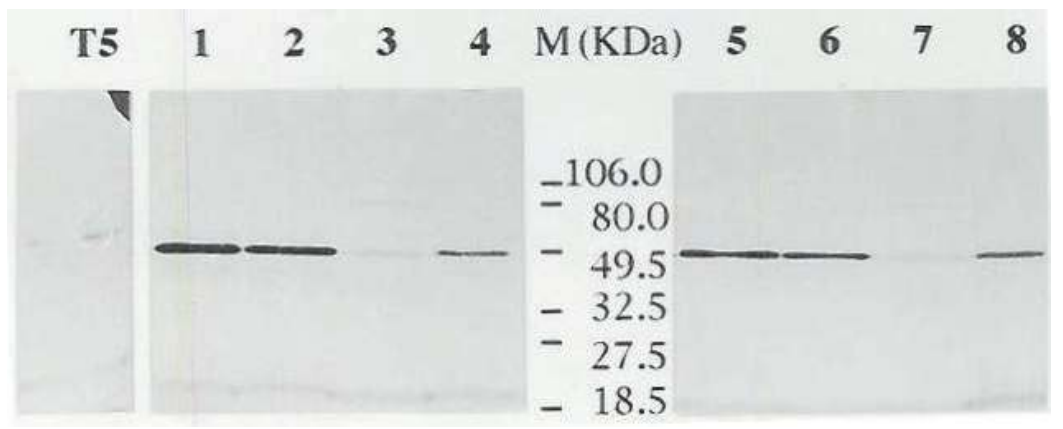

Fig. 5. Autolysin activity of ammonium sulfate precipitated whole cell extract.

In an attempt to enhance the solubility of this enzyme, we proceeded to evaluate the effects of various salts, detergents and organic compounds on the extraction process. Cells were therefore treated as described earlier, however after centrifugation to remove cell debris, the cell debris was treated with either $5 \mathrm{M} \mathrm{LiCl}, 5 \mathrm{M} \mathrm{NaCl}, 60 \%$ (v/v) acetonitrile or $20 \%(\mathrm{w} / \mathrm{v})$ SDS. These cell debris were extracted for one hour, centrifuged and the supernatant was lyophylized to concentrate the product. The use of $\mathrm{LiCl}$ and SDS did enhance protein recovery and the extraction of the autolysin. SDS recovered $80.99 \%$ of the proteins while $\mathrm{LiCl}, \mathrm{NaCL}$ and acetonitrile recovered $13.14 \%, 3.46 \%$ and $2.42 \%$ protein respectively.

Figure 6 presents the protein profiles (6a) and autolytic activity (6b) for these four different extractions of cell debris. Lanes (1 and 2), (3 and 4), (5 and 6) and (7 and 8) correspond respectively to 1.5 and $15 \mu \mathrm{g}$ of proteins from treatments $\mathrm{LiCl}(5 \mathrm{M}), \mathrm{NaCl}(5 \mathrm{M})$, acetonitrile $(60 \%)(\mathrm{v} / \mathrm{v})$ and SDS $(20 \%)(\mathrm{w} / \mathrm{v})$.

We can see from these results that SDS induces a better extraction of protein, followed by $\mathrm{LiCl}$ and $\mathrm{NaCl}$. The protein profiles from these three extracts strongly ressemble each other. However, when looking at the specific extraction of autolysin PA49.5 (Fig. 6b) we can see that we observe autolytic activity only when the cell debris is extracted with $\mathrm{LiCl}$ or SDS. The SDS extract in fact shows the main autolysin PA49.5 and two minor autolytic bands. The extraction with $\mathrm{LiCl}$ shows the main autolysin and one minor autolytic band at the higher protein concentration. Two faint bands are visible in the high protein concentration lane of the $\mathrm{NaCl}$ extract and no autolysins were extracted with acetonitrile. These results confirm that SDS is in fact a detergent of choice in the extraction and solubilization of autolysins (Leclerc \& Asselin, 1989; Lemee et al., 1994, 1995; Lortal et al., 
1997). One of the limitations of SDS, as previously mentioned, is the fact that it affects the tri-dimensional structure of the protein thereby reducing or eliminating its biological activity. However, we have also shown that $\mathrm{LiCl}$ could be efficacious in the extraction process as well, with the added advantage of having less effect on the biological activity of the enzyme. A challenge in the use of $\mathrm{LiCl}$ is the amount of protein and enzyme recovered. Our results also indicate that the autolysin is present in the cell wall debris. This confirms the data presented in the literature that autolysins are linked to bacterial cell walls (Brown, 1972; Brown, 1973; Lemee et al., 1995)

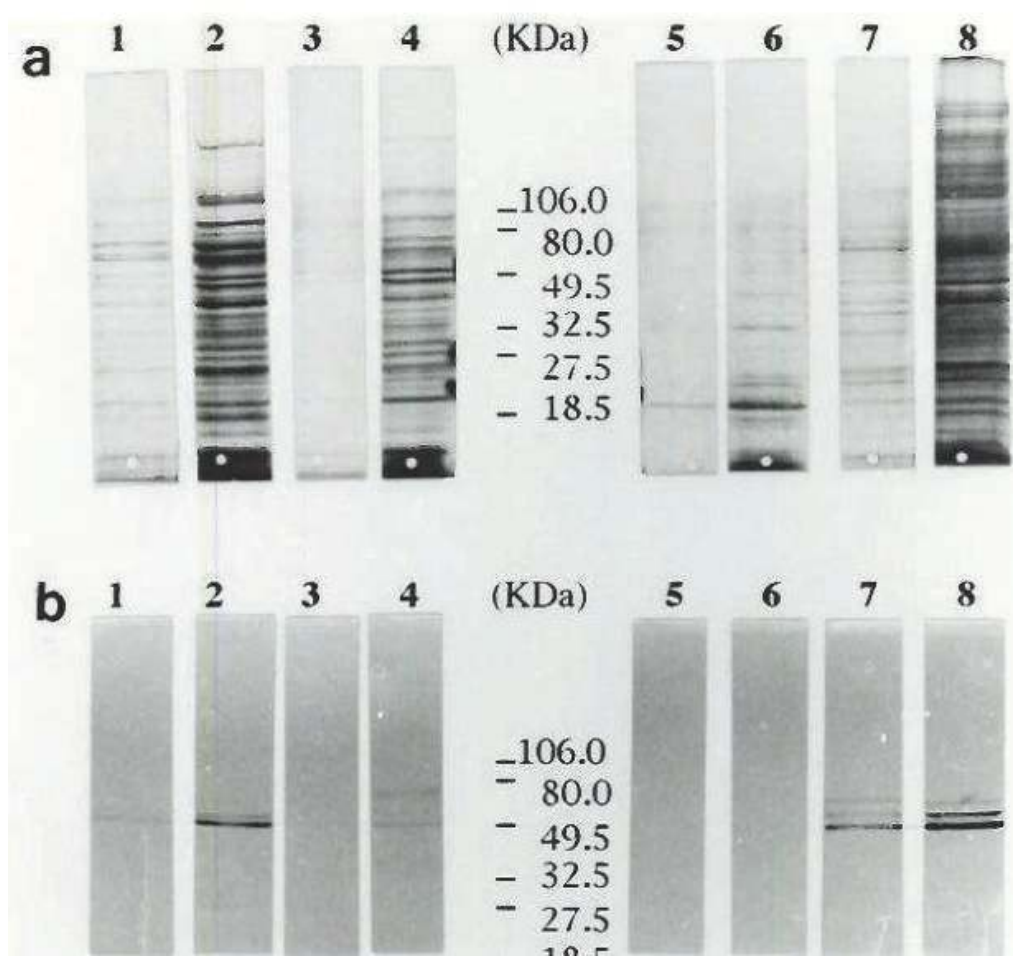

Fig. 6. The protein profile (a) and autolytic activity (b) of cell debris extracted with $\mathrm{LiCl}$, $\mathrm{NaCl}$, acetonitrile and SDS.

In order to more thoroughly investigate the use of $\mathrm{LiCl}$ and SDS in the extraction process and to try to increase protein yield, extraction was performed on whole cells rather than the cell debris. Three types of treatments were compared in this study, the $\mathrm{LiCl}$ extract from cell debris (A), the $\mathrm{LiCl}$ extract from whole cells (Awc) and the SDS extract from whole cells (Dwc).

From these results we can see once again that SDS does allow the best protein extraction and the highest protein recovery. In using it on whole cells the quantity of protein extracted was increased 2-fold compared to that extracted from cell debris (data not shown). The extraction using $\mathrm{LiCl}$ on whole cells increased the amount of protein extracted by 3 fold when compared to $\mathrm{LiCl}$ used on cell debris. Therefore, the use of whole cells as a starting 
material certainly yields more interesting results in terms or protein recovery. Figure 7 presents the results of the autolysin assay for the whole cell extracts.

\begin{tabular}{lccccc}
\hline \multicolumn{1}{c}{ Treatment } & $\begin{array}{c}\text { Optical density } \\
\mathbf{7 5 0} \mathbf{~ n m}\end{array}$ & $\begin{array}{c}\text { [protein] } \\
\mathbf{m g} / \mathbf{m l}\end{array}$ & $\begin{array}{c}\text { Volume of } \\
\text { the } \\
\text { suspension } \\
\mathbf{( m )}\end{array}$ & $\begin{array}{c}\text { Protein } \\
\mathbf{( m g})\end{array}$ & $\begin{array}{c}\text { \% protein } \\
\text { recovery/1g }\end{array}$ \\
\hline A- LiCl cell debris & 0.31 & 1.06 & 3.10 & 3.30 & 0.33 \\
\hline $\begin{array}{l}\text { Awc - LiCl on } \\
\text { whole cells }\end{array}$ & 0.55 & 2.35 & 4.10 & 9.63 & 0.96 \\
\hline $\begin{array}{l}\text { Dwc - SDS on } \\
\text { whole cells }\end{array}$ & 0.68 & 3.04 & 13.00 & 39.56 & 3.96 \\
\hline
\end{tabular}

Table 1. presents the results of the levels of protein recovery using these different extraction methods.

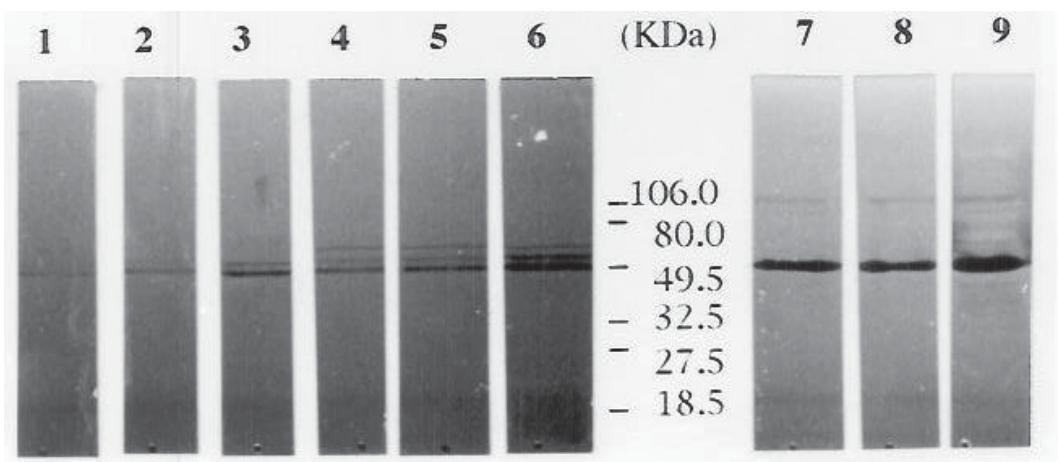

Fig. 7. Autolysin activity for three dilutions of protein $(1 / 10,1 / 5$ and 1$)$ extracted from cell debris with $\mathrm{LiCl}$ (lanes 1-3), from whole cells with SDS (lanes 4-6) and from whole cells with $\mathrm{LiCl}$ (lanes 7-9).

We noticed that when used on whole cells, SDS showed the same autolysin extraction pattern ( 3 bands) as when used on cell debris (Fig. 6 b lanes 7 and 8 ). Lanes 7 to 9 illustrate that the action of $\mathrm{LiCl}$ on whole cells allows an increase in autolysin concentration. With this treatment on whole cells, the $1 / 10$ dilution $(3 \mu \mathrm{g} / \mu \mathrm{l})$ is sufficient to triple the activity when compared to that of the SDS whole cell extract. According to Brown et al (1970), the main approach to the extraction of autolysins, whether soluble or not, requires the use of $\mathrm{LiCl}$. Our results concure with this proposal.

The $\mathrm{LiCl}$ treated whole cell extract was centrifuged and the precipitate (Pwc) was conserved and resuspended while the supernatant (Swc) was precipitated with ammonium sulfate as previously described in order to further purify the autolysin in quesiton, PA49.5. The following saturations fractions were obtained: 0-20, 20-40, 40-100\%. Protein concentrations were determined for all fractions as well as the initial precipitate $(\mathrm{Pwc})$ and are presented in Table 2. The results demonstrate that protein is still found in the precipitate, representing approximately $19 \%$ of the protein. Precipitation with ammonium sulfate recovers $81.81 \%$ of proteins from the supernatant. This is a relatively good recovery rate and indicates that 
ammonium sulfate precipitation is efficient in precipitation proteins. An interesting observation is made regarding protein quantities in the initial whole cell extract (Awc) from Table 1 compared to the amount of protein recovered in precipitated supernatant. We had $9.63 \mathrm{mg}$ of protein in the initial extract (Awc Table 1), however only $1.348 \mathrm{mg}$ of protein were detected in total from all fractions and the precipitate added together (Table 2). This $1.348 \mathrm{~g}$ includes the $0.255 \mathrm{mg}$ of proteins found in the initial precipitate (Pwc) that should in fact be considered insoluble proteins. Thus, only $14 \%$ of the protein is in fact recovered overall after ammonium sulfate precipitation. We noticed a white precipitate on the walls of the Microcon-10 ultrafiltration column during these tests. This white precipitate became less prevalent as the concentration of ammonium sulfate increased. This could therefore be the source of our lost proteins during this process.

\begin{tabular}{|c|c|c|c|c|c|c|}
\hline Treatment & Sam & aple type & $\begin{array}{c}\text { [protein] } \\
\mathrm{mg} / \mathrm{ml}\end{array}$ & $\begin{array}{c}\text { Volume of } \\
\text { suspension }(\mathrm{ml})\end{array}$ & $\begin{array}{l}\text { Protein } \\
\text { (mg) }\end{array}$ & $\begin{array}{l}\% \text { protein } \\
\text { recovered }\end{array}$ \\
\hline \multirow[t]{2}{*}{$\begin{array}{l}\text { Precipitate of } \\
\text { whole cell extract }\end{array}$} & & PwC & 0.850 & 0.300 & 0.255 & 18.92 \\
\hline & & $0-20 \%$ & 1.500 & 0.300 & 0.450 & 33.38 \\
\hline \multirow[t]{2}{*}{$\begin{array}{l}\text { Supernatant of } \\
\text { whole cell extract }\end{array}$} & Swc & $20-40 \%$ & 0.860 & 0.645 & 0.555 & 41.17 \\
\hline & & $40-100 \%$ & 0.250 & 0.250 & 0.088 & 6.53 \\
\hline
\end{tabular}

Table 2. Protein assays of ammonium sulfate precipitation fractions of the whole cell extract (Awc) supernatant (Swc) and precipitate (Pwc). Total protein recovered is $1.348 \mathrm{mg}$.

Since the protein amount was so high in the first whole cell precipitate (Pwc) we decided to analyse it further to obtain its protein profile and evaluate the presence of autolysin PA49.5 in this precipitate. The results of this analysis proved to be very interesting. PA49.5 was found to be present and active in the precipitate and in all the ammonium sulfate fractions. Our evaluation of the intensity of the band in the precipitate lead us to believe that approximately $80 \%$ of the autolysin from the original whole cell extract treated with $\mathrm{LiCl}$ (Awc) is found in the precipitate (Pwc). This confirms our initial tests that indicate that the autolysin is indeed insoluble in an aqueous solution.

There are three possible explanations to the insolubility observed for our enzyme. Firstly, we may not be working at the appropriate $\mathrm{pH}$ to ensure enzyme activity. A study on the effects of different $\mathrm{pHs}$ would allow us to discover the ideal $\mathrm{pH}$ for the maximum solubilization of the enzyme in question. Secondly, it is possible that the concentrations of the enzyme during the extraction cause the aggregation of the enzyme in micelles whereby the hydrophobic regions would be oriented towards the outside or inside, or that there is still a lot of cell wall debris left that contain the lytic enzymes. In these cases, the use of organic solvant or detergents or even a natural autolysis would facilitate solubilisation. Thirdly, it is possible that the autolysin in question is linked to a fatty acid or to teichoic acide or lipoteichoic acid. This would render the enzyme insoluble if the complexe is not disrupted. 
Three hypotheses and experimental approaches to resolving the problem were then proposed.

Hypothesis 1: A study of the effects of different $\mathrm{pH}$ on the Awc extract will allow us to find the ideal $\mathrm{pH}$ for the solubilization of the protein. This supposes that after centrifugation, the autolysin with then be found in the supernatant, not the precipitate as it is now.

Hypothesis 2: If the autolysins are still linked to the cell wall debris, a natural hydrolysis will allow the breakage of this bond and therefore enhance solubilization.

Hypothesis 3: If the autolysins of the whole cell extract (Awc) are linked to hydrophobic compounds such as fatty acids or teichoic acide, the use of detergents, either non ionic or zwitterionic, will break these bonds and solubilize the enzyme.

\section{Hypothesis 1: The effect of $\mathrm{pH}$ on the solubility of PA49.5}

Whole cells were extracted as previously described in $5 \mathrm{M} \mathrm{LiCl}$. The lyophilisat was suspended in deionised water and the protein concentration was determined. The solubilization of the proteins was performed in different buffers at pHs ranging from 4 to 9 for a final concentration of $1 \mathrm{mg} / \mathrm{ml}$ of protein in a final volume of $100 \mu \mathrm{l}$. These were incubated overnight and then centrifuged. The supernatant (Swc) was removed and the precipitate was resuspended in the same volume of water. The amount of protein was measured in all precipitates and supernatants and autolytic activity was evaluated as previously presented in a renatured SDS gel containing cell walls as the substrate. The main results of this experiment was that the amount of protein in the precipitate was found to be approximately half of that found in the supernatant (Swc) for all the $\mathrm{pH}$ values tried except for that of $\mathrm{pH}$ 4.0. If this protein found in the precipitate is the autolysin in question, this would mean that the $\mathrm{pH}$ has no effect on solubilisation of the protein. Figure 8 presents the results of the autolysis activity assay in a denaturing gel containing the cell walls as substrates. Gel 1 (Lanes 1 to 9) contain the precipitates (Pwc) and Gel 2 (lanes 1' to 9') contain the supernatants (Swc) at the following pHs: 4, 5, 6, 6.5, 7, 7.5, 8, 8.5, 9), Lane 10 is the uncentrifuged whole cell extract Awc as the control.

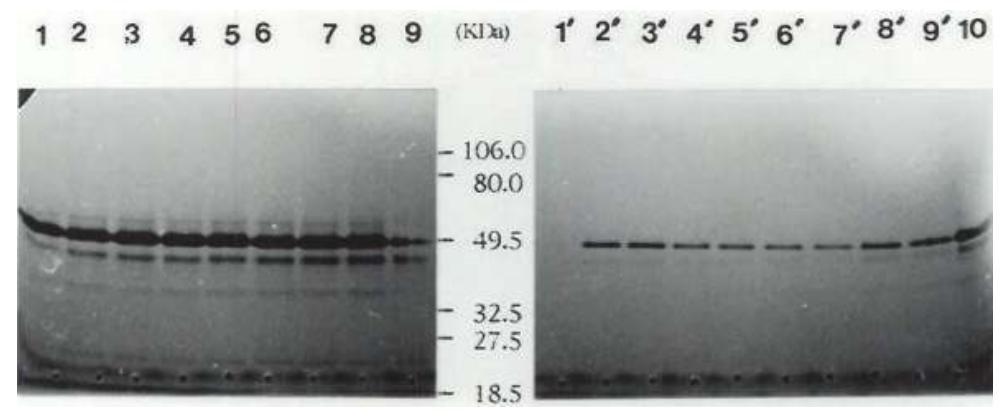

Fig. 8. The effect of $\mathrm{pH}$ on the solubility of PA49.5.

We can conclude from the results presented in figure 8 that the precipitate contains approximately $4 \mathrm{x}$ more autolysin than does the supernatant and that the $\mathrm{pH}$ has little effect on this results. We can therefore refute our first hypothesis that the working $\mathrm{pH}$ was reducing the solubility of the enzyme. 


\section{Hypothesis 2: The effect of a natural hydrolysis over time on the solubility of PA49.5}

The whole cell extract (Awc) is incubated at $37^{\circ} \mathrm{C}$ for $8 \mathrm{~h}$, and samples removed at hourly intervals. Autolytic activity was evaluated in an acrylamide gel containing cell walls as the substrate. Figure 9 presents the results of the autolysis analysis of the aliquots. Lanes 1 to 8 and $1^{\prime}$ to $8^{\prime}$ represents respectively the precipitates of the extract (Pwc) and the supernatants of the extract (Swc) for each hourly aliquot. Lanes 9 and $9^{\prime}$ are the precipitate and supernatant of the control at time 0 . We can see the main autolysin with the molecular weight of 49.5 and a smaller minor autolysin. The incubation time did not have an effect on the extraction of the enzyme. All precipitates are identical to each other. The activity in the supernatants was much lower than that in the precipitates and did vary somewhat with time, the most activity being obtained after 6 hours of incubation. It is, however, difficult to assess if this difference is significant.

The use of an acetate buffer did not improve natural hydrolysis. A simple dilution in water indicates that the actual dilution is the primary reason for the presence of PA49.5 in the supernatant and not the $\mathrm{pH}$ nor the time of incubation. We already know it is insoluble in water, however, a dilution of the Awc in water could explain why the PA49.5 is in an aggregate form thereby inhibiting its solubilization.

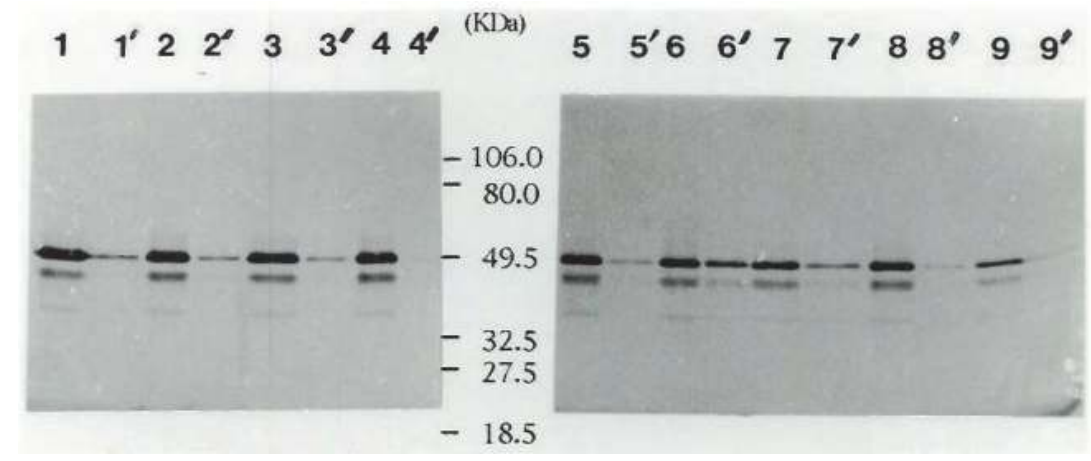

Fig. 9. The effect of natural autolysis of the whole cell extract (Awc) over time.

In an assay to study the effects of autolysis in vitro on enzyme solubility, the cell wall substrate was added to the whole cell extract (Awc) and incubated for $16 \mathrm{~h}$. Autolysis was determined by measuring the reduction of optical density over time. Autolysis induced in vitro by the Awc autolysins on the cell wall substrate increased with time. Figure 10 shows that after $16 \mathrm{~h}$ of incubation autolysis reached $52 \%$. At the $8 \mathrm{~h}$ point on Figure 9 only $35.55 \%$ autolysis has actually been achieved.

The presence of lytic activity only after extraction in $\mathrm{LiCl}$ shows that most of the autolysines of the Awc are soluble, contrary to the results obtained with the precipitate and the supernatant (results not shown). Analysed after treatment in $3 \mathrm{M}$ and $5 \mathrm{M} \mathrm{LiCl}$ for 5 hours, the enzymes in the precipitate and the lyophilisate of the supernatant showed no lytic activity in the acrylamide gel containing the cell wall substrate, except for the untreated control. This suggests that the free autolysines were unstable in the $\mathrm{LiCl}$ and can induce the inhibitory effects of these free enzymes. It has been previously reported that LiCL can be inhibitory when the extracted product is not immediately suspended in 
water before dialysis (Brown, 1973; Shockman et Höltje, 1994; Lawrence et Glaser, 1972; Herbold et Glaser, 1975b).

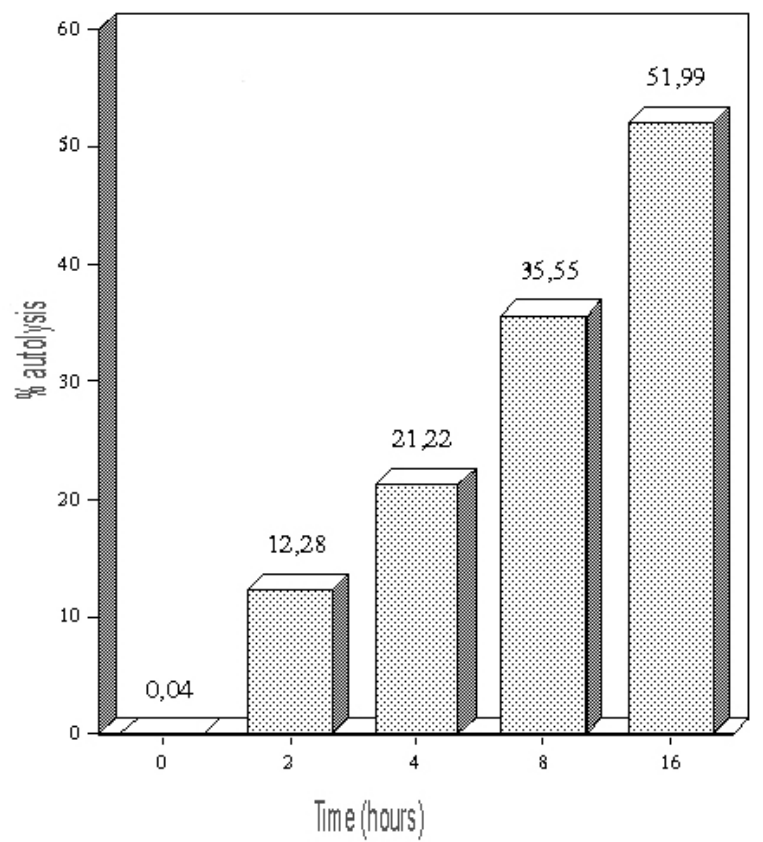

Fig. 10. The effects of autolysis by whole cell extract (Awc) in vitro on suspended cell walls

\section{Hypothesis 3: The action of detergents on the solubility of PA49.5}

Various concentrations of CHAPS (Zwitterionic; 0.2, 2.0 and 6.0\%), Triton X-100 (non ionic; $0.2,2.0$ and $6.0 \%)$ and $\mathrm{LiCl}(3 \mathrm{M}, 5 \mathrm{M}$ and $7 \mathrm{M})$ were separately added to the whole cell extract (Awc). After incubation, the mixtures were centrifuged, the precipitate was resuspended in water and both precipitate and supernatant were assayed for autolytic activity as previously described. The results show that the precipitate and supernatants for the CHAPS and Triton- $X$ treatments are very similar to each other. There does appear to be more solubilization of the autolysin with these detergents as the activity in the supernatant is now approximately half of that found in the precipitate. At the highest CHAPS concentration there does appear to be some inhibition of solubility as the activity in the supernatant is reduced with this treatment. In fact, for both these detergents, the enzyme activity decreases as the concentration of the detergent increases. The difference between these two detergents is that CHAPS is easier to eliminate by dialysis, while Triton X-100 is very difficult to eliminate from the extract. A concentration of between 0.2 and $2 \%$ CHAPS would provide excellent results.

After the treatment with $\mathrm{LiCl}$ and the subsequent dialysis, most of the autolysin was found in the precipitate. This would suggest that the compound that renders the enzyme insoluble is also found in the supernatant due to the effects of $\mathrm{LiCl}$. It is only after dialysis that the insoluble complex is reconstituted. A dilution of $50 \%$ shows that a part of this 
complex is solubilized. The concentration of the initial whole cell extract (Awc) can explain this phenomenon; the lower the concentration of the extract, the greater the solubilization. Dilution of the extract by $50 \%$ is not however sufficient to resolve the insolubility problem.

We also evaluated the effect of incubation time $(2,4,8$ and 24 hours) in the presence of CHAPS, lysozyme and $\mathrm{LiCl}$. CHAPS had a positive effect on the solubilization of the enzyme, however the incubation time did not affect the extraction of the enzyme. For the samples treated with lysozyme we found that the intensities of the activity in the supernatants tested was identical to that of the control. Higher concentrations of lysozyme did however negatively affect the amount of autolysin in the supernatant. We did notice the presence of a new autolysin in the extracts treated with lysozyme. This was a very important discovery as we can conclude that there must be trace amounts of cell wall still present in the extract on which the lysozyme is working. Lysozyme is involved in the degradation of the cell wall, in particular the cleavage of bonds between specific peptidoglycans (N-acetylmuramic acid and $\mathrm{N}$-acetlyglucosamine) (Cottagnoud \& Tomawsz, 1993). The fact that we did not observe more PA49.5 in the supernatant of extracts treated with lysozyme indicates that the compounds involved in binding the PA49.5 into an insoluble complex are not in fact cell wall debris. The time course study of the $\mathrm{LiCl}$ treatment indicates once again that most of the enzyme is present in the precipitate. This indicates that the dialysis performed during the extraction must be the determining step in the production of this insoluble complex.

When the original cell extract (Awc) produced in $5 \mathrm{M} \mathrm{LiCl}$ is diluted and incubated for 2 or 4 hours, we observed interesting results. The incubation time did have an effect on enzyme activity as compared to the control, and we found that the more dilute extract had more enzyme activity. At a dilution of $1 \%$ the activity in the supernatant was approximately equal to that of the precipitate. At $10 \%$ concentration, the activity was found primarily in the precipitate. Since there is an effect of extract concentration on the solubility, we treated several dilutions of cell extract (Acw; $1,3.5$ and $7 \%$ ) with different concentrations of $\mathrm{LiCl}(1$, 2.5 and $5 \mathrm{M})$ to solubilize the lipid-PA49.5 complexes. These extracts were then incubated and dialyzed after centrifugation as previously described. The combination of $0.25 \mathrm{M} \mathrm{LiCl}$ with the dilution of $7 \%$ Awc was the only one to have intense activity in the supernatant, however most of the activity still remains in the precipitate.

The combined effects of detergents and heat were then evaluated on a dilute sample of the whole cell extract. Various concentrations of $\mathrm{LiCl}$, SDS $(0,1 \mathrm{M}, 0.5 \mathrm{M}$ and $1 \mathrm{M})$, and CHAPS $(0.04,0.08,0.1,0.2 \%$ and $0.4 \%, \mathrm{w} / \mathrm{v})$ were added to a dilution of $3 \%$ Awc treated and incubated at $100^{\circ} \mathrm{C}$. After incubation with the various treatments, the extracts were centrifuged and the precipitation was resuspended in water. The supernatant was once again dialysed then concentrated using a Speed-Vac and the lyophilisate was resuspended in a denaturing buffer. Activity was assayed as previously described.

The results show that the combination of temperature and detergents does influence the solubility of the enzyme. We found that the treatments with $\mathrm{LiCl}$ did allow the solubilization of the enzyme, however some activity still remained in the precipitate. The $\mathrm{LiCl}$ was however less efficient than SDS which completely solubilized the enzyme, with all the activity being present in the supernatant. We observed that this intensity of the activity 
in the supernatant decreased as the concentration of SDS increased. When analyzed in a non denaturing native gel electrophoresis, the controls and the SDS treated extracts did not have any activity, however the $\mathrm{LiCl}$ treated extracts did have some weak activity. This suggests that the presence of $\mathrm{LiCl}$, at least in the short term, does protect the solubilized protein against effects of the temperature. Also, the absence of activity in the SDS treated extracts confirms that this detergent in fact inhibits the solubilization of the enzyme.

Contrary to the results obtained with the detergent SDS, the detergent CHAPS completely solubilized the enzyme under these conditions. A concentration of $0.1 \%$ CHAPS is sufficient for the solubilization. It has been suggested that the presence of CHAPS in a solubilized protein can interfere with enzyme activity assays (Hjelmeland \& Chrambach, 1984). In this case the conditions of the assay may have to be adjusted. The solubilizing effect of CHAPS does require a heat treatment. Unheated samples have enzyme activity only in the precipitate, not the supernatant, illustrating the importance of the heat treatment with CHAPS.

In an attempt to eliminate contaminating proteins from the cell extract, we performed sequential precipitations in the presence of CHAPS. In this process, the initial extract (Awc) was centrifuged and the supernatant (S1) removed. The precipitate (P1) was resuspended in water and centrifuged. The supernatant was removed and the precipitate (P2) was resuspended in water and the process was repeated 3 more times to produce ultimately S1 to S5 and P5. The final precipitate (P5) was resuspended in 1\% CHAPS and heated for 2 minutes at $100{ }^{\circ} \mathrm{C}$. After cooling, the suspension was centrifuged and the supernatant was dialysed and lyophilized giving the CHAPS supernatant (Sc). The precipitate was dissolved in water to give the CHAPS precipitate (Pc). The CHAPS supernatant was further processed by centrifugation to produce the final supernatant (Sf) and the final precipitate (Pf). The following samples were then evaluated for PA49.5 activity in a polyacrylamide gel containing the cell wall as the substrate: S1-S5 combined, Sc, Sf, P1, P5, Pc and Pf. The results of this experiment are presented in figure 10. We notice that there is more enzyme activity in the last precipitate P5 as compared to the first precipitate (P1). The absence of activity in the CHAPS precipitate (Pc) indicate the complete solubilization of the enzyme, as confirmed by the strong level of activity in the CHAPS supernatant (Sc).The presence of the enzyme in the first five supernatants (S1-S5) indicate that there is a loss of enzyme throughout the process, representing approximately one half of the enzyme. We can also observe on figure 10 that when the CHAPS supernatant $(\mathrm{Sc})$ is dialysed, the PA49.5 once again is unsolubilized and is found in the final precipitate (Pf). No enzyme activity was found in the final supernatant (Sf). Therefore, we can conclude that the elimination of the CHAPS detergent by dialysis stimulates the production of the insoluble PA49.5 complex. We also conclude that the lipophylic compound that binds the PA49.5 is present in the solubilized extract and that neither dialysis nor centrifugation can remove it completely. The detergent CHAPS is the only compound capable of being dialysed that does not compromise the activity of the autolysin (Hjelmeland \& Chrambach, 1984), however, it must not be complexed.

All these results bring us back to our starting point, the difficulty in purifying this autolysin. We propose that during dialysis three types of insoluble complexes can be formed: PA49.5insoluble compound complex, PA49.5-CHAPS complex, or insoluble compound-CHAPS complex. In the first case, we have the situation where the insoluble complex is present in 
the actual extraction conditions used. However, in the second case, the PA49.5-CHAPS complex, there is the high probability that this will be eliminated by dialysis. This bond is weaker than that between the PA49.5 and the insoluble compound that is probably a teichoic or fatty acid (Brown et al., 1970). Thus, after dialysis, it would be possible to identify specific activity if this second complex was formed. The third complex is more difficult to explain. It could in fact intervene as a contaminant in the second type of complex proposed. The presence of the insoluble compound-CHAPS complex would greatly impact the purification of PA49.5. It would therefore be advantageous to find an alternative detergent, perhaps non-ionic, that could more easily be dialyzed and does not denature the enzyme in question or facilitate the production of unwanted bonds. CHAPs is a zwitterionic detergent, having both a positive and negative charge that cancel each other making it an uncharged detergent. PA49.5 is an acidic autolysin, meaning it has a negative charge. It could therefore form a complex with the positively charged end of the CHAPS detergent. The insoluble compound could also be charged or neutral. If it is negatively or positively charged, it could bind to the autolysine and/or the CHAPS. If this is the case, the problem of solubility would present itself as we experienced it in our work.

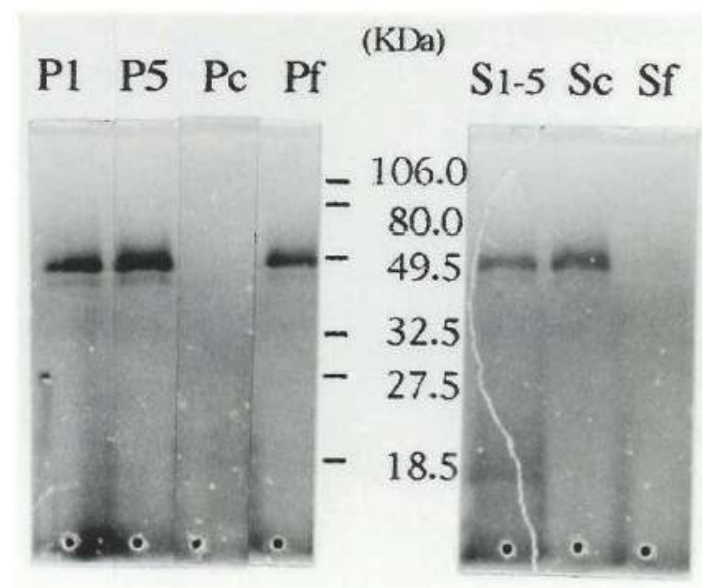

Fig. 11. The effects of sequential precipitations combined with CHAPS on the solubility of the enzyme PA49.5

Our work allowed us to comprehend more clearly the challenges encountered in the purification of an autolysin such as PA49.5 from Lactococcus lactis sp cremoris. The extraction from whole cells rather than cell wall debris was much more effective. Our results from the ammonium sulfate precipitation indicate the limitations of this procedure for the isolation of an insoluble protein. Our results were quite interesting regarding the use of $\mathrm{LiCl}$ during the extraction of the enzyme, however, the use of non-ionic detergents should be investigated. Our study will also allow other researchers to avoid some of the difficulties that might be encountered during the purification of cytoplasmic or membrane bound enzymes. The results of our study clearly show that we must absolutely take into account the nature of the various detergents, the extractions conditions and the specific type of enzyme when deciding on a purification strategy 


\section{References}

Bonner, P.L.R. (2007). Protein purification. Taylor and Francis Group, New York, NY.

Brown, W.C. (1972). Binding and release from cell walls: a unique approach to the purification of autolysins, Biochemical and Biophysical Research Communications Vol 47: 993-996.

Brown, W.C., Fraser, D.K. \& Young, F.E. (1970). Problems in purification of a Bacillus subtilis autolytic enzyme caused by association with teichoic acid, Biochemica Biophysica Acta, Vol.198: 308-315.

Brown, W.C. (1973). Rapid method for extracting autolysins from Bacillus subtilis. Applied Microbiology 25, 295-300.

Chen W., Druhan L.J., Chen C.-A., Hemann C., Chen Y.-R., Berka V., Tsai A.-L. \& Zweier J.L. (2010). Peroxynitrite Induces Destruction of the Tetrahydrobiopterin and Heme in Endothelial Nitric Oxide Synthase: Transition from Reversible to Irreversible Enzyme Inhibition, Biochemistry Vol.49: 3129-3137.

Cottagnoud, p. \& Tomasz, A. (1993). Triggering of pneumococcal autolysis by lysozyme, The Journal of infectious diseases Vol.167: 684-690.

Dako, E., Asselin, A., \& Simard, E.R. (2003b). Partial purification and characterization of the main autolysins from Lactococcus lactis subsp, cremoris atcc 9596 Journal of Food Technology Vol.1 (2): 63-74.

Dako, E., El Soda, M., Vuillemard, J.C. \& Simard, R.E. (1995). Autolytic properties and aminopeptidase activities of lactic acid bacteria, Food Research International Vol.28: 503-509.

Dako, E., Jankowski, C.J. Bernier, A.M., Asselin, A., \& Simard, R.E. (2008). A new approach for the purification and characterisation of PA49.5, the main prebiotic of Lactococcus lactis subsp. Cremoris, International Journal of Food Microbiology Vol.126: 186-194.

Dolinger, D.L., Daneo-Moore, L. \& Shockman, G.D. (1989). The second peptidoglycan hydrolase of Streptococcus faecium ATCC 9790 covalently binds penicillin, Journal of Bacteriology Vol.171(8): 4355-4361.

Doonan, S. (2004a). Concentration of extracts, in Paul Cutler, Protein Purification Protocoles: second edition, Humana Press Inc., Totowa, NJ. pp. 85-90.

Doonan, S. (2004b). Bulk purification by fractional precipitation, in Paul Cutler, Protein Purification Protocoles: second edition, Humana Press Inc., Totowa, NJ. pp. 117124

Fisher, W., Koch, H.U. \& Rösel, P. (1980). Alanine ester-containing native lipoteichoic acids do not act as lipoteichoic acid carrier. Isolation, structural and functional Characterization, Journal of Biological Chemistry Vol.255: 4555-4562.

Garavito, R.M. (1991). In Crystallisation membrane (Michel. Ed). CRC Press, Boca Raton, FL, P. 89.

Helenius, A., McCaslin, D.F.R. \& Tanford, C. (1979). Properties of detergents, Methods in Enzymology Vol.56: 734-749.

Herbold, D.R. \& Glaser, L. (1975). Interaction of N-acetylmuramic acid L-alanine amidase with cell wall polymers. Journal of Biological Chemistry 250, 7231-7238. 
Hjelmeland, L.M. \& Chrambach, A. (1984). Solubilization of functional membrane proteins, Methods in Enzymology Vol.104: 305-318.

Höltje, J.V. \& Tomasz, A. (1975). Specific recognition of choline residues in the cell wall teichoic acid by the $\mathrm{N}$-acetylmuramyl-L-alanine amidase of Pneumococcus, Journal of Biological Chemistry Vol.250: 6072-6076.

Kawagishi, S., Araki, Y. \& Ito, E. (1980). Separation and characterization of an autolytic endo-ß-glucosaminidase from Bacillus cereus, European Journal of Biochemistry Vol.112: 273-281.

Lawrence, C. \& Glaser, L. (1972). Purification of $N$-acetylmuramic acid-L-alanine amidase from Bacillus magneterium, Journal of biological Chemistry Vol.247: 5391-5397.

Leclerc, D. \& Asselin, A. (1989). Detection of bacterial cell wall hydrolases after denaturing polyacrylamide gel electrophoresis. Canadian Journal of Microbiology 35, 749-753.

Lemee, R., Lortal, S., Cesselin, B. \& Heijenoort, J.V. (1994). Involvement of an NAcetylglucosaminidase in Autolysis of Propionibacterium freudenreichii CNRZ 725, Applied and Environmental Microbiology Vol.60(2): 4351-4358.

Lemee, R., Lortal, S. \& Heijenoort, J.V. (1995). Autolysis of dairy propionibacteria: isolation and renaturing gel electrophoresis of the autolysins of Propionibacterium freudenreichii CNRZ 725. Lait 75, 345-365.

Lever T.M., Cogdell R.J. \& Lindsay J.G. (1994). In Membrane Protein Expression System - A Guide (G.W. Gould, ed). Portland Press, London, pp. 1.

Linke, D. (2009). Detergents: an overview, Methods of Enzymology Vol.463: 603-617.

Lortal, S., Lemée, R. \& Valence, F. (1997). Autolysis of thermophilic lactobacilli and dairy propionibacteria: a review, Lait Vol.77: 133-150.

Marshak, D.R., Kadonaga, J.T., Burgess, R.R., Knuth, M.W., Brennan,W.A. \& Lin, S.-H. (1996). Strategies for Protein Purification and Characterization. Cold Spring Harbor Laboratory Press, pp. 1-396.

Motoyuki S., Komatsuzawa H., Akiyama T., Hong Y.-M., Oshida T., Miyake Y., Yamaguchi T. \& Suginaka H. (1995). Identification of Endo-b-N-Acetylglucosaminidase and $\mathrm{N}$ Acetylmuramyl-L-Alanine Amidase as Cluster-Dispersing Enzymes in Staphylococcus aureus, Journal of Bacteriology, pp. 1491-1496

O'Fagain, C. (2004). Lyophylisation of proteins, in Paul Cutler, Protein Purification Protocoles: second edition, Humana Press Inc., Totowa, NJ. pp. 309-322.

Potvin, C., Leclerc, D., Tremblay, G., Asselin, A. \& Bellmare, G. (1988). Cloning, sequencingand expression of a Bacillus bacteriolytic enzyme in E, coli, Molecular and General Genetics Vol.214: 241-248.

Privé, J.J. (2007). Detergents for the stabilization and crystallization of membrane proteins. Methods Vol.41: 388-397.

Shockman, G.D. \& Höltje, J.V. (1994). Microbial peptidoglycan (murein) hydrolases. Comprehensive biochemistry. I. In: Ghuysen, J.M., Hakenbeck, R. (Eds.), Bacterial Wall Elsevier of Science B.V., London, pp. 133-166.

Shockman, G.D., Pooley, H.M., \& Thompson, J.S. (1967). Autolytic enzyme system of Streptococcus faecalis. III. Localization of the autolysin at the sites of cell wall synthesis, Journal of Bacteriology Vol.94 (5): 1525-1530. 
Valence, F. \& Lortal, S. (1995). Zymogram and preliminary characterization of Lactobacillus helveticus autolysins, Applied and Environmental Microbiology Vol.61: 3391-3399.

Ward, W. W. \& Swiatek, G. (2009). Protein purification. Current Analytical Chemistry Vol.5: 85-105. 


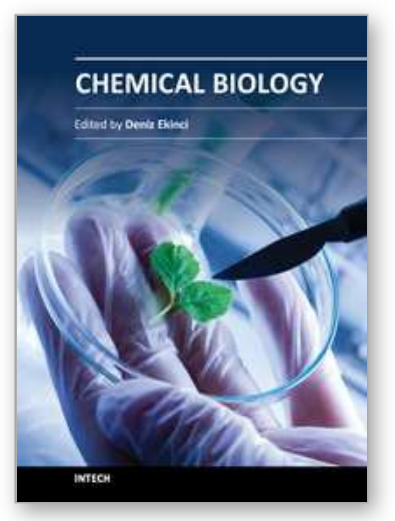

\author{
Chemical Biology \\ Edited by Prof. Deniz Ekinci
}

ISBN 978-953-51-0049-2

Hard cover, 444 pages

Publisher InTech

Published online 17, February, 2012

Published in print edition February, 2012

Chemical biology utilizes chemical principles to modulate systems to either investigate the underlying biology or create new function. Over recent years, chemical biology has received particular attention of many scientists in the life sciences from botany to medicine. This book contains an overview focusing on the research area of protein purification, enzymology, vitamins, antioxidants, biotransformation, gene delivery, signaling, regulation and organization. Particular emphasis is devoted to both theoretical and experimental aspects. The textbook is written by international scientists with expertise in synthetic chemistry, protein biochemistry, enzymology, molecular biology, drug discovery and genetics many of which are active chemical, biochemical and biomedical research. The textbook is expected to enhance the knowledge of scientists in the complexities of chemical and biological approaches and stimulate both professionals and students to dedicate part of their future research in understanding relevant mechanisms and applications of chemical biology.

\title{
How to reference
}

In order to correctly reference this scholarly work, feel free to copy and paste the following:

Etienne Dako, Anne-Marie Bernier, Adjéhi Thomas Dadie and Christopher K. Jankowski (2012). The Problems Associated with Enzyme Purification, Chemical Biology, Prof. Deniz Ekinci (Ed.), ISBN: 978-953-51-0049-2, InTech, Available from: http://www.intechopen.com/books/chemical-biology/the-problems-associated-withenzyme-purification

\section{INTECH}

open science | open minds

\author{
InTech Europe \\ University Campus STeP Ri \\ Slavka Krautzeka 83/A \\ 51000 Rijeka, Croatia \\ Phone: +385 (51) 770447 \\ Fax: +385 (51) 686166 \\ www.intechopen.com
}

\author{
InTech China \\ Unit 405, Office Block, Hotel Equatorial Shanghai \\ No.65, Yan An Road (West), Shanghai, 200040, China \\ 中国上海市延安西路65号上海国际贵都大饭店办公楼 405 单元 \\ Phone: +86-21-62489820 \\ Fax: $+86-21-62489821$
}


(C) 2012 The Author(s). Licensee IntechOpen. This is an open access article distributed under the terms of the Creative Commons Attribution 3.0 License, which permits unrestricted use, distribution, and reproduction in any medium, provided the original work is properly cited. 